\title{
The protective effect of Vitamin D and combination with liv-52 on lipid profiles in carbon tetrachloride-induced liver disease in Wistar rats
}

\author{
J. Sivakumar ${ }^{1}$, K. Ponnazhagan², T. Gopalakrishnan ${ }^{3}$ \\ ${ }^{1}$ Associate Professor, Department of Biochemistry, Dhanalakshmi Srinivasan Medical College and Hospital, \\ Perambalur, ${ }^{2}$ Assistant Professor, Department of Biochemistry, Meenakshi Medical College Hospital and Research \\ Institute, ${ }^{3}$ Assistant Professor, Department of Biochemistry, Melmaruvathur Adhiparasakthi Institute of Medical \\ Sciences and Research, Kanchipuram, Tamil Nadu, India
}

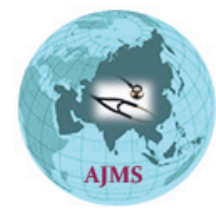

A B S TR A C T

Background: Liver is the largest gland, accounts for approximately $2.5 \%$ of total body weight and also liver called as the metabolic "engine-room of the body." Liver plays role in both metabolism as well as biochemical transformation. Therefore, it is vital to maintain a healthy liver for overall health and well-being. However, liver is continuously exposed to exogenous substances such as toxins, drugs, and alcohol which can ultimately lead to various liver disorders. Liver diseases today are one of the most fatal diseases globally. Aims and Objectives: The aim of the present study was to evaluate lipid peroxidation (LPO) and lipid profile levels of Vitamin $D$ and combination with Liv-52 on carbon tetrachloride induced liver disease in rats. Materials and Methods: Thirty-six adult male Albino Wistar rats weighing 150-200 g were used in this study. Liver disease was induced in rats by administration of Carbon tetrachloride $\left(\mathrm{CCl}_{4}\right)$ intraperitoneally at the dose of $1 \mathrm{~mL}$ mixed with $50 \%$ of olive oil twice a week for 5 weeks, 3 days interval between each dose, after confirmation of liver disease treated with Vitamin D and Liv-52 for 5 weeks. Results: The levels of LPO were significantly decreased in Vitamin D and Liv-52 treated animals when compared with $\mathrm{CCl}_{4}$ induced animals. Total cholesterol, free cholesterol, phospholipids, and triglycerides (TGs) levels were significantly reduced when compared with $\mathrm{CCl}_{4}$ induced rats. However, the levels of ester cholesterol and free fatty acids (FFAs) were significantly increased in Vitamin D and Liv-52 treated animals when compared with $\mathrm{CCl}_{4}$ induced animals. Conclusion: Vitamin D and Liv-52 effectively reduced the LPO levels. Treatment with Vitamin D and Liv-52, the levels of total and free cholesterol, phospholipids, and TGs were significantly reduced and treatment with both combinations highly reduced all these levels when compared with $\mathrm{CCl}_{4}$ induced animals. And treatment with Vitamin $\mathrm{D}$ and Liv52 , the ester cholesterol and FFAs levels were increased.

Key words: Carbon tetrachloride; Lipid profile; Liv-52; Liver disease; Vitamin D

\section{Access this article online}

\section{Website:}

http://nepjol.info/index.php/AJMS DOI: 10.3126/ajms.v12i11.39219

E-ISSN: 2091-0576

P-ISSN: 2467-9100

Copyright (c) 2021 Asian Journal of Medical Sciences

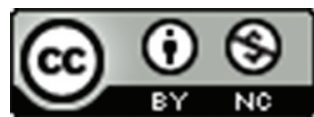

This work is licensed under a Creative Commons Attribution-NonCommercial 4.0 International License.

\section{INTRODUCTION}

Liver is the largest gland in the body weighing about $1500 \mathrm{~g}$ in an adult and accounts for approximately 2.5\% of total body weight. ${ }^{1}$ Liver is called as the metabolic "engine-room of the body." Liver performs vital role in wide range of functions such as metabolism of nutrients, synthesis and secretion of plasma proteins, storage of energy, detoxification of drugs, helps in digestion, and fat metabolism by excretion of bile salts; and excretion of end products of metabolism through urine. ${ }^{3}$ Liver plays role in both metabolism as well as biochemical transformation. Therefore, it is vital to maintain a healthy liver for overall health and well-being. However, liver is continuously

Address for Correspondence:

Dr. J. Sivakumar, Associate Professor, Department of Biochemistry, Dhanalakshmi Srinivasan Medical College and Hospital, Perambalur

Tamil Nadu, India. Mobile: +91-8220950427. E-mail: drshivakumar21@gmail.com 
and variedly exposed to exogenous substances such as environmental toxins, chemical drugs, and alcohol which can ultimately lead to various liver disorders, generally presenting as a distinct pattern of diseases such as hepatocellular, cholestasis (obstructive), or mixed type of liver disorders. ${ }^{4}$ Liver injuries may lead to hepatic failure and finally death. Liver diseases today are one of the most fatal diseases globally. ${ }^{5}$

Carbon tetrachloride $\left(\mathrm{CCl}_{4}\right)$ is an important model agent to study the pathogenesis of liver injury. The mechanism of $\mathrm{CCl}_{4}$ hepatotoxicity has been thoroughly studied since $1967, \mathrm{CCl}_{4}$-induced toxicity is a multifactorial process involving the generation of $\mathrm{CCl}_{4}$-derived free radicals. ${ }^{6}$ The first step is metabolic activation of $\mathrm{CCl}_{4}$ by CYP2E1, whereby $\mathrm{CCl}_{4}$ is converted to free radicals (trichloromethyl and trichloromethyl peroxy radicals). The second step is binding of these radicals to antioxidant enzymes, including the sulfhydryl (protein thiol) groups of glutathione. In the third step, these overproduced free radicals increase membrane lipid peroxidation (LPO), bind covalently to macromolecules, deplete ATP, and interfere with calcium homeostasis. $^{7}$

Most hepatotoxic chemicals damage liver cells because the formation of LPO products leads to spread of free radicals reactions. The important role of lipids in cellular components emphasizes the significance of understanding the mechanisms and consequences of LPO in biological systems. Polyunsaturated fatty acids (PUFAs) serve as excellent substrates for LPO because of the presence of active bis-allylic methylene groups. The carbon-hydrogen bonds on these activated methylene units have lower bond dissociation energies, making these hydrogen atoms more easily abstracted in radical reactions. ${ }^{8}$ The susceptibility of a particular PUFA toward peroxidation increases with an increase in the number of unsaturated sites in the lipid chain. ${ }^{9}$

Vitamin D is a secosteroid hormone known for its critical role in calcium and skeletal homeostasis. It is obtained either from dietary sources or synthesized endogenously. Clinical experimental studies proved that, Vitamin D is now involved in an important modulator of the immune response to infection ${ }^{10}$ and also been implicated in the cellular proliferation and differentiation mechanisms. Many experimental studies are generally accepted that Vitamin D status is related to both innate and adaptive immune system. Vitamin D receptor is express in almost all immune cells, including T lymphocyte, B lymphocyte, neutrophils, and antigen presenting cells, such as macrophages, monocytes, and dendritic cells have prompted the idea that Vitamin D could have a vital role in the regulation of immune responses. ${ }^{11}$ All these immune cells also express the mitochondrial
Vitamin D-activating enzyme, 1- $\alpha$ hydroxylase (CYP27B1) and that have possess the ability to convert $25(\mathrm{OH}) \mathrm{D}$ to 1 , $25(\mathrm{OH}) 2 \mathrm{D}$. This reaction is regulated by circulating levels of $25(\mathrm{OH}) \mathrm{D}$ and can also be induced by activation of specific toll-like receptors (TLRs) which act as pathogen detectors. Thus, 1, 25(OH)2D could play important roles in both innate and adaptive immune responses.

Many experimental studies are suggested that Vitamin $\mathrm{D}$ has beneficial effects in liver diseases by activating and regulating innate and adaptive immunity. Vitamin $\mathrm{D}$ increases innate immunity, ${ }^{12}$ and stimulating the mechanisms associated with the elimination of pathogen agents through the secretion of antibacterial proteins, such as macrophage phagocytosis, cathelicidin, beta-defensin, and favoring chemotaxis. ${ }^{13}$ An increased immune response can cause tissue damage; in this condition, Vitamin D activate an adequate innate immune response by regulating the expression of several TLRs and by decreasing the production of pro-inflammatory cytokines such as Platelet-Derived Growth Factor, Transforming Growth Factor- $\beta$, Tumor Necrosis Factor- $\alpha$, and Interferon. An inverse relationship between Vitamin D levels and the expression of TLR2, TLR4, and TLR9 in monocytes has been observed, as has a decrease in the expression of these innate immunity receptors after the administration of $1 \alpha$, $25(\mathrm{OH}) 2 \mathrm{D} .{ }^{14}$ These three TLRs are primarily related to the inflammation and fibrosis of the liver.

Vitamin D may inhibit various aspects of inflammation, which have been established as key pathogenic mechanisms in atherosclerosis. Recently, some experimental studies reported associations between hyperlipidemia and Vitamin D deficiency. ${ }^{15,16}$ Moreover, preliminary findings from clinical trials have suggested that Vitamin D supplementation may reduce cardiovascular mortality. Wang et al.,' ${ }^{17}$ meta-analysis showed that low serum 25-hydroxy Vitamin D (25[OH]D) levels are associated with an increased risk of cardiovascular diseases.

Liv-52 is an indigenous multiherbal hepatotonic that has been widely used as a hepatoprotective agent in various liver disease. ${ }^{18}$ The Liv-52 formulation incorporates renowned Ayurvedic plant principles Capparis spinosa, Cichorium intybus, Solsnum nigrum, Cassia occidentalis, Terminalia arjuna, Achillea millefolium, Tamarix gallica, and Mandur bhasma ${ }^{19}$ and these herbs has been reported to provide considerable protection against liver damage by $\mathrm{CCl}_{4}$. The antiperoxidative activity of Liv-52 prevents the loss of functional integrity of the cell membrane, maintains cytochrome P-450 enzyme system, and lipid membrane. It has been involved in functional efficiency of the liver by promoting detoxification and thus protecting from harmful food and medication toxins, maintaining healthy levels of liver enzymes. ${ }^{20}$ 
In this regard, a recent study in rats showed that the active metabolite of Vitamin D and herbal products of liv-52 may prevent lipid molecule formation though the reduction of free radical scavenging activities and LPO levels in the in vivo model.

\section{Aims and objectives}

The aim of the present study was to evaluate lipid peroxidation (LPO) and lipid profile levels of Vitamin $\mathrm{D}$ and combination with Liv-52 on carbon tetrachloride induced liver disease in rats.

\section{MATERIALS AND METHODS}

\section{Animal models}

Thirty-six adult male Albino Wistar rats weighing 150$200 \mathrm{~g}$ were used for the study and animals were purchased from Biogen Laboratory Animal Facility, Bengaluru, Karnataka and housed in Meenakshi Medical College and Research Institute, Kanchipuram, Tamil Nadu. The animal were well housed in polypropylene cages under hygiene conditions $(24 \times 14 \mathrm{~cm}$ and 6 rats per cage) and maintained in a controlled environmental condition of temperature $\left(23 \pm 2^{\circ} \mathrm{C}\right)$ and relative humidity $(50-70 \%)$ on alternatively $12 \mathrm{~h}$ light/dark cycles. The animals were allowed to have standard pellet diet (Gold Mohor rat feed, M/s. Hindustan Lever Ltd., Mumbai) and water ad libitum. The rats were acclimatized to laboratory condition for 1 week before commencement of the experiment. This research work on Wistar rats was obtained and approved by the Institutional Animal Ethical Committee (REG No. $765 / 03 / \mathrm{ca} /$ CPCEA).

\section{Study protocol}

Animals were divided into six groups comprising six rats each. Group I served as normal healthy control animals, Group II rats treated with $\mathrm{CCl}_{4}$ intraperitoneally $(1 \mathrm{~mL} / \mathrm{kg}$ b.w., $50 \% \mathrm{CCl}_{4}$ in olive oil; 2 days/week) for 5 weeks. Group III rats received Vitamin D dissolved in distilled water at dose levels of $500 \mathrm{IU} / \mathrm{kg}$ b.w., with $\mathrm{CCl}_{4}$ (as above) daily for 5 weeks. Group IV were administrated $1 \mathrm{~mL} / \mathrm{kg}$ b.w., of Liv-52 with $\mathrm{CCl}_{4}$ (as above) daily for 5 weeks. Group V rats received both Vitamin D and Liv-52, with $\mathrm{CCl}_{4}$ daily for 5 week (as above). Group VI rats received Vitamin D and Liv-52 dissolved in distilled water at dose levels of $500 \mathrm{IU}$ and $1 \mathrm{~mL} / \mathrm{kg}$ b.w., without intoxication with $\mathrm{CCl}_{4}$, respectively. At the end of experimental period, the animals were deprived of food overnight and anesthetized by exposing to diethyl ether and then sacrificed by cervical decapitation. $2 \mathrm{ml}$ of the blood were collected from all the rats through the tail and retro-orbital venous plexus under ether-induced anesthesia, into plain dry test tube (without anticoagulant) and serum was separated and used for biochemical assays. Liver tissue was immediately dissected out and washed in ice-cold saline and patted dry and weighed. Approximately $100 \mathrm{mg}$ tissue from liver was taken and homogenized $(10 \% \mathrm{w} / \mathrm{v})$ with $0.1 \mathrm{M}$ TrisHCL buffer in ice cold condition. The supernatants were separated, stored at $4^{\circ} \mathrm{C}$ for 1 week and used for biochemical assays, were determined using spectrophotometric method (Shimadzu UV 1800 spectrophotometer).

\section{Drugs and chemicals}

CC14, Vitamin D were purchased from sigma chemical, Liv-52 purchased from Himalaya Drug Company and other chemicals were purchased from SRL chemicals.

\section{Assay of LPO}

The level of lipid peroxides was assayed by the method of Ohkawa et al., ${ }^{21}$ To $0.2 \mathrm{ml}$ of homogenate, $0.2 \mathrm{ml}$ of SDS, $1.5 \mathrm{ml}$ of acetic acid, and $1.5 \mathrm{ml}$ of TBA were added. The mixture was made up to $4 \mathrm{ml}$ with water and then heated in an oil bath at $95^{\circ} \mathrm{C}$ for 60 min using glass ball as a condenser. After cooling, $1 \mathrm{ml}$ of water and $5 \mathrm{ml}$ of $\mathrm{n}$-butanol/pyridine mixture were added and shaken vigorously. After centrifugation at $4000 \mathrm{rpm}$ for $10 \mathrm{~min}$, the absorbance of organic layer was measured at $532 \mathrm{~nm}$.

\section{Estimation of total cholesterol (TC)}

TC content was estimated by the method of Parekh and Jung. ${ }^{22} 0.1 \mathrm{ml}$ of the serum was taken and mixed with $3 \mathrm{ml}$ with ferric chloride-uranyl acetate reagent. Then $2 \mathrm{ml}$ of sulfuric acid-ferrous sulfate reagent was added to all the tubes and the contents were mixed well. After 20 min the color developed was read at $540 \mathrm{~nm}$ using a photochem colorimeter.

\section{Estimation of free cholesterol}

Free cholesterol was estimated by the method of Leffler and McDougald. ${ }^{23} 0.3 \mathrm{ml}$ of aliquots were dried and mixed with $1 \mathrm{ml}$ of isopropanol and centrifuged. To the supernatant, $0.5 \mathrm{ml}$ of digitonin reagent was added and the contents were stored at $4^{\circ} \mathrm{C}$ for $30 \mathrm{~min}$. Then, it was centrifuged at $3000 \mathrm{rpm}$ for $10 \mathrm{~min}$. The supernatant was decanted and the precipitate was washed twice with $1 \mathrm{ml}$ of acetone. The precipitate was dissolved in $3 \mathrm{ml}$ of ferric chloride-uranyl acetate reagent to which $2 \mathrm{ml}$ of sulfuric acid-ferrous sulfate reagent was added. After $20 \mathrm{~min}$, the color developed was read at $530 \mathrm{~nm}$ using the photochem colorimeter.

\section{Estimation of ester cholesterol}

Ester cholesterol was measured by subtraction of free cholesterol come TC.

\section{Estimation of phospholipids}

Phospholipids were estimated by the method of Rouser et al., ${ }^{24}$ To $0.1 \mathrm{ml}$ of was taken and mixed with $0.5 \mathrm{ml}$ of 
ammonium molybdate and ascorbic acid were added and the mixture was kept in a boiling water bath for 6 min. The blue color developed was read at $710 \mathrm{~nm}$ using a photochem colorimeter.

\section{Estimation of triglycerides (TGs)}

TGs were estimated by the method of Rice ${ }^{25}$ To $0.1 \mathrm{ml}$ of the sample was mixed with $1 \mathrm{ml}$ of chloroformmethanol mixture and $50 \mathrm{mg}$ of activated silicic acid was added, shaken vigorously and allowed to stand for $30 \mathrm{~min}$. After centrifugation, to $0.5 \mathrm{ml}$ of supernatant, as well as standard and blank, $0.5 \mathrm{ml}$ of alcoholic potassium hydroxide was added and the mixture was saponified in a $60-70^{\circ} \mathrm{C}$ water bath for $20 \mathrm{~min}$. To this $0.5 \mathrm{ml}$ of $0.2 \mathrm{~N}$ sulfuric acid was added and kept in a boiling water bath for $10 \mathrm{~min}$. After cooling the tubes, $0.1 \mathrm{ml}$ of sodium metaperiodate was added and allowed to stand for $10 \mathrm{~min}$. The excess periodate was reduced by the addition of $0.1 \mathrm{ml}$ of sodium meta arsenite. Then $5.0 \mathrm{ml}$ of chromotrophic acid was added, mixed thoroughly and kept in a boiling water bath for $30 \mathrm{~min}$. After cooling, $0.5 \mathrm{ml}$ of thiourea solution was added and the color developed was read at $570 \mathrm{~nm}$ using a photochem colorimeter.

\section{Estimation of free fatty acid (FFA)}

FFA content was estimated by the method of Hron and Menahan. ${ }^{26} 0.2 \mathrm{ml}$ of sample was mixed with $6.0 \mathrm{ml}$ of chloroform: heptane:methanol solvent and was shaken vigorously. $200 \mathrm{mg}$ of activated silicic acid was added, shaken and left aside for $30 \mathrm{~min}$. The solution was then centrifuged and the supernatant was transferred to a tube containing $2 \mathrm{ml} \mathrm{Cu}$-TEA reagent. The contents were agitated using a mechanical shaker for $20 \mathrm{~min}$. The mixture was separated in to two phases by centrifugation. $2 \mathrm{ml}$ of upper layer was mixed with $1 \mathrm{ml}$ of color reagent and shaken well. The yellow color developed was read at $430 \mathrm{~nm}$ in a photochem colorimeter.

\section{Statistical analysis}

All analyses in the statistical evaluation were carried out using the Statistical Package for Social Sciences for Windows version 21.0 software, one-way ANOVA method was used for the comparison of variables between groups and the group mean were compared by Duncan's Multiple Range Test. Statistical probability $\mathrm{P}<0.05$ was considered to be significant.

\section{RESULTS}

The level of LPO in the liver and serum was found to be significantly higher $(\mathrm{P}<0.001)$ in the hepatotoxic induced Group II animals when compared with Group I control animals. Treatment with Vitamin D caused a significant reduction $(\mathrm{P}<0.001)$ in their levels when compared to hepatotoxic bearing animals, and treatment with liv-52 caused a significant decreased $(\mathrm{P}<0.001)$ in their levels when compared to CCl4-treated animals. However, treatment with combination of both Vitamin $\mathrm{D}$ and Liv-52 caused a very much significant reduction $(\mathrm{P}<0.001)$ in the level of LPO when compared with hepatotoxic bearing rats. There was no significant difference in the LPO levels between the control rats and the control rats treated both Vitamin D and liv-52 and (G-VI) (Table 1).

The determination of lipid profile showed that the exposure of rats to $\mathrm{CCl}_{4}$ produce significantly higher $(\mathrm{P}<0.001)$ in the serum level of TC, free cholesterol, TGs, and phospholipids while ester cholesterol and FFAs were decreased significantly $(\mathrm{P}<0.001)$ when compared to the normal healthy control rats. However, the exposure to Vitamin D and liv-52 caused significant reduction $(\mathrm{P}<0.001)$ of serum $\mathrm{TC}$, free cholesterol, TGs, and phospholipids while ester cholesterol and FFAs were increased significantly $(\mathrm{P}<0.001)$ when compared to the drug-induced control group. However, the exposure to combination of both Vitamin D and liv-52 caused very much significant reduction $(\mathrm{P}<0.001)$ of serum $\mathrm{TC}$, free cholesterol, TGs, and phospholipids while serum levels of ester cholesterol and FFAs were significant elevation $(\mathrm{P}<0.001)$ in rats when compared to the drug induced control group. There was no significant difference in the lipid profile levels between the control rats and the control rats treated both Vitamin D and liv-52 and (GVI) (Table 2).

\section{DISCUSSION}

The liver is largest organ and is easy target for toxicity because of its role in clearing and metabolizing chemicals through the process called detoxification. ${ }^{27}$ The most commonly used approach to induce toxin-mediated experimental liver fibrosis is the periodic administration of $\mathrm{CCl}_{4}$ in rats. ${ }^{28}$ It was used extensively in animal models of acute hepatic failure in the seventies and early eighties. More recently, it has been used in the development of cirrhosis animal models following its gastric and intraperitoneal administration. ${ }^{29}$ The most studies rely on the $\mathrm{CCl}_{4}^{-}$ model to induce toxic liver fibrosis in rats due to the good comparability, excellent reproducibility, and moderate burden for the animals. ${ }^{28}$

The toxic effect of $\mathrm{CCl}_{4}$ was due to trichloromethyl radical produced during oxidative stress. ${ }^{29}$ The liver injury induced by $\mathrm{CCl}_{4}$ increases the number of infiltrated Kupffer cells, 


\begin{tabular}{|c|c|c|c|c|c|c|}
\hline Particulars & $\begin{array}{l}\text { Group } \\
\text { I (Control) }\end{array}$ & $\begin{array}{l}\text { Group II (CCI } \\
\text { Induced) }\end{array}$ & $\begin{array}{c}\text { Group III (Vitamin } \\
\text { D treated }\end{array}$ & $\begin{array}{c}\text { Group IV (Liv-52 } \\
\text { treated) }\end{array}$ & $\begin{array}{l}\text { Group V (Both } \\
\text { Vitamin D and } \\
\text { Liv-52 treated) }\end{array}$ & $\begin{array}{c}\text { Group } \\
\text { VI (Both } \\
\text { Vitamin D and } \\
\text { Liv-52) }\end{array}$ \\
\hline $\begin{array}{l}\text { Liver (nmoles of } \\
\text { MDA liberated/mg } \\
\text { protein) }\end{array}$ & $1.1 \pm 0.12$ & $4.2 \pm 0.3^{a^{\star}}$ & $3.2 \pm 0.25^{b *}$ & $2.8 \pm 0.19^{b *}$ & $1.9 \pm 0.17^{b *}$ & $1.1 \pm 0.11$ \\
\hline $\begin{array}{l}\text { Serum (nmoles of } \\
\text { MDA liberated/mg } \\
\text { protein) }\end{array}$ & $1.63 \pm 0.15$ & $2.16 \pm 0.22^{\mathrm{a}^{*}}$ & $1.6 \pm 0.12^{b *}$ & $1.7 \pm 0.11^{\mathrm{b} *}$ & $1.62 \pm 0.12^{\mathrm{b} *}$ & $1.55 \pm 0.13$ \\
\hline
\end{tabular}

\begin{tabular}{|c|c|c|c|c|c|c|}
\hline Particulars & $\begin{array}{l}\text { Group } \\
\text { I (Control) }\end{array}$ & $\begin{array}{l}\text { Group } \\
\text { II (CCI4 } \\
\text { Induced) }\end{array}$ & $\begin{array}{c}\text { Group III (Vitamin } \\
\text { D treated }\end{array}$ & $\begin{array}{c}\text { Group IV (Liv-52 } \\
\text { treated) }\end{array}$ & $\begin{array}{l}\text { Group V (Both } \\
\text { Vitamin D and } \\
\text { Liv-52 treated) }\end{array}$ & $\begin{array}{c}\text { Group VI (Both } \\
\text { Vitamin D and } \\
\text { Liv-52) }\end{array}$ \\
\hline $\begin{array}{l}\text { Total } \\
\text { cholesterol (mg/dl) }\end{array}$ & $149.1 \pm 11.0$ & $197.0 \pm 15.0^{\mathrm{a} *}$ & $158.4 \pm 12.3^{\mathrm{b} *}$ & $155.6 \pm 12.7^{b *}$ & $152.3 \pm 7.2^{\mathrm{b*}}$ & $148.0 \pm 9.5$ \\
\hline $\begin{array}{l}\text { Free } \\
\text { cholesterol }(\mathrm{mg} / \mathrm{dl})\end{array}$ & $91.8 \pm 7.0$ & $151.1 \pm 13.2^{\mathrm{a} *}$ & $129.0 \pm 8.0^{\mathrm{b} *}$ & $124.5 \pm 9.5^{\mathrm{b} *}$ & $110.7 \pm 9.8^{\mathrm{b} *}$ & $90.8 \pm 6.5$ \\
\hline $\begin{array}{l}\text { Ester } \\
\text { cholesterol (mg/dl) }\end{array}$ & $57.8 \pm 5.15$ & $33.6 \pm 2.3^{a *}$ & $42.5 \pm 2.9^{b *}$ & $45.2 \pm 6.6^{\mathrm{b} *}$ & $47.1 \pm 6.6^{\mathrm{b} *}$ & $59.48 \pm 4.5$ \\
\hline $\begin{array}{l}\text { Phospholipids (mg/ } \\
\text { dl) }\end{array}$ & $157.9 \pm 11.4$ & $225.9 \pm 15.7^{a^{*}}$ & $186.7 \pm 14.1^{\mathrm{b} *}$ & $183.5 \pm 9.6^{\mathrm{b} *}$ & $166.9 \pm 10.0^{\mathrm{b} *}$ & $156.4 \pm 8.8$ \\
\hline $\begin{array}{l}\text { Triglycerides (mg/ } \\
\text { dl) }\end{array}$ & $48.1 \pm 4.3$ & $74.9 \pm 5.8^{\mathrm{a} *}$ & $60.8 \pm 4.9^{\mathrm{b} *}$ & $58.3 \pm 9.0^{\text {b* }}$ & $53.3 \pm 2.8^{\mathrm{b} *}$ & $48.4 \pm 4.3$ \\
\hline $\begin{array}{l}\text { Free fatty } \\
\text { acids }(\mathrm{mg} / \mathrm{dl})\end{array}$ & $28.7 \pm 2.3$ & $14.1 \pm 1.0^{\mathrm{a} *}$ & $20.6 \pm 1.3^{\mathrm{b} *}$ & $22.1 \pm 1.7^{\mathrm{b} *}$ & $26.38 \pm 2.2^{\mathrm{b} *}$ & $29.08 \pm 2.5$ \\
\hline
\end{tabular}

Each value is expressed as mean \pm SD for six rats in each group. ${ }^{a}$ As compared with Group I, ${ }^{b}$ As compared with Group II. Statistical significance: ${ }^{*} \mathrm{P}<0.001$

neutrophils, macrophages, lymphocytes, and natural killer cells which further induced activation of liver resident macrophages and/or chemo attraction of extra hepatic cells (e.g., neutrophils and lymphocytes)..$^{30}$ Liver fibrosis, inflammation, and injury were induced by release of activated macrophages. ${ }^{31}$

Lipids are more easily attacked by the activated metabolites of $\mathrm{CCl}_{4}$ resulting in damage to intracellular membranes and the plasma membrane. ${ }^{32}$ Radical formation and LPO are the predominant cellular mechanisms involved in the development of fatty liver caused by $\mathrm{CCl}_{4}{ }^{33}$ Extensive accumulation of lipids is regarded as a pathological condition, and when the accumulation becomes chronic, fibrotic changes occur in the cells that progress to cirrhosis and impaired liver function. ${ }^{34}$ An increase in the levels of cholesterol, TGs, and FFAs was noted in plasma and tissues. $\mathrm{CCl} 4$ increases the synthesis of fatty acids and TGs from acetate. This could be due to the transport of acetate into the liver cell, resulting in increased substrate (acetate) availability. In $\mathrm{CCl}_{4}$ toxicity, the synthesis of cholesterol is also increased. ${ }^{35}$
On the other hand, $\mathrm{CCl}_{4}$ lowers b-oxidation of fatty acids and hydrolysis of TGs. This increases the availability of fatty acids to esterification. ${ }^{36}$ Reports have also shown that during $\mathrm{CCl}_{4}$ toxicity, fat from the peripheral adipose tissue is translocated to the liver and kidney leading to its accumulation. ${ }^{37}$ Moreover, the synthesis of apolipoproteins is inhibited by $\mathrm{CCl}_{4}^{38}$ subsequently resulting in the decreased synthesis of lipoproteins. A decrease in the secretion of bile acids is also reported.

Phospholipids are the vital components of biomembranes. They are more susceptible to $\mathrm{CCl}_{4}$-induced LPO than other lipid classes ${ }^{39}$. A decrease in the levels of phospholipids in liver and kidney is probably due to an increase in phospholipase activity. During normal lipoprotein metabolism, phospholipids are extensively converted into TGs. ${ }^{40} \mathrm{CCl}_{4}$-induced inhibition of lipoprotein-associated TG export may also result in increased release of phospholipids from these tissues. An increase in phospholipid levels in brain and heart could be due to increased phospholipid content of their membranes. 
Vitamin D deficiency is associated with not only cardiovascular disease itself but also cardiovascular risk factors. ${ }^{41}$ Low Vitamin D levels could result in dyslipidemia, and lipid abnormalities, that is, an increase in TG, TC, and low-density lipoprotein cholesterol levels and a decrease in high-density lipoprotein cholesterol (HDL-C) level have been identified as important risk factors for atherosclerosis and cardiovascular disease in adulthood. ${ }^{42}$ Observational studies have demonstrated that high levels of Vitamin D are associated with a favorable lipid profile, whereas low levels of Vitamin D are associated with an atherogenic lipid profile. ${ }^{43}$

The Ayurvedic formulation of Liv-52 exhibits potent hepatoprotective properties against chemically induced hepatotoxicity. It restores the functional efficiency of the liver by protecting the hepatic parenchyma and promoting hepatocellular regeneration. The antiperoxidative activity of Liv-52 prevents the loss of functional integrity of the cell membrane, maintains cytochrome P-450 enzyme system and lipid membrane. ${ }^{44} \mathrm{Liv}-52$ is known to improve the functional efficiency of the liver by promoting detoxification and thus protecting from harmful food and medication toxins, maintaining healthy levels of liver enzymes. Liv-52 is also known to support liver's normal ability to burn fat and maintain body's metabolic homeostasis.

Experimental studies are reported that Vitamin D and Liv52 possesses hypocholesterolemic action and this could be due to a decrease in absorption of cholesterol or an increase in HDL-C. This indicates that Vitamin D and Liv52 mobilizes excess cholesterol from extrahepatic tissues to liver where it is catabolized. Vitamin D also increases the activity of 7a-hydroxylase, which converts cholesterol to bile acids, facilitating the biliary cholesterol excretion. The decrease in the levels of TGs and phospholipids might be due to decreased FFA synthesis by Vitamin D, which may suppress the enzymes involved in FFA synthesis.

In the present study proved that, the levels of LPO were significantly decreased in Vitamin D and Liv-52 treated animals when compared with $\mathrm{CCl}_{4}$ induced animals. TC, free cholesterol, phospholipids, and TGs levels were significantly reduced when compared with $\mathrm{CCl}_{4}$ induced rats. However, the levels of ester cholesterol and FFAs were significantly increased in Vitamin D and Liv-52 treated animals when compared with $\mathrm{CCl}_{4}$ induced animals.

\section{CONCLUSION}

Vitamin D and Liv-52 effectively reduced the LPO levels and increased total and free cholesterol, phospholipids, and
TGs levels. And treatment with Vitamin D and Liv-52, the ester cholesterol and FFAs levels were increased.

\section{ACKNOWLEDGEMENT}

I wish to thank Meenakshi Medical College Hospital and Research Institute and MAHER, deemed to be University for granting me permission to carry out the project.

\section{REFERENCES}

1. Sheila S and Dooley J. Diseases of the Liver and Biliary System. $9^{\text {th }}$ ed. Osney Mead, Oxford: Blackwell Scientific Publications; 1993.

https://doi.org/0000/5828/26/L-G-0000582826-0002360880

2. Maton $A$, Jean $H$, McLaughlin $C W$, Warner $M Q$, Lattart $D$ and Wright JD. Human Biology and Health Englewood Cliffs. New Jersey: Prentice Hall; 1993.

https://doi.org/32308337

3. Rajesh MG and Latha MS. Protective activity of Glycyrrhiza glabra Linn. On carbon tetrachloride-induced peroxidative damage. Indian J Pharmacol. 2004;36(5):284-287.

http://doi.org.br/ph04098

4. Kumar V, Modi PK and Saxena KK. Exploration of hepatoprotective activity of aqueous extract of Tinospora cordifolia an experimental study. Asian J Pharm Clin Res. 2013;6(1):87-91.

https://doi.org/286546326

5. Marcellin P and Kutala B. Liver diseases: A major, neglected global public health problem requiring urgent actions and largescale screening. Liver Int. 2018;38(1):2-6.

https://doi.org/10.1111/liv.13682

6. Recknagel RO, Glende EA Jr., Dolak JA and Waller RL. Mechanisms of carbon tetrachloride toxicity. Pharmacol Ther. 1989;43(1):139-154.

https://doi.org/10.1016/0163-7258(89)90050-8

7. Tyson CA, Story DL and Stephens RJ. Ultrastructural changes in isolated rat hepatocytes exposed to different $\mathrm{CCl} 4$ concentrations. Biochem Biophys Res Commun. 1983;114(2):511-517.

https://doi.org/10.1016/0006-291x(83)90810-0

8. Davies AG, Griller D, Ingold KU, Lindsay DA and Walton JC. An electron spin resonance study of pentadienyl and related radicals: homolytic fission of cyclobut-2-enylmethyl radicals. J Chem Soc Perkin Trans. 1981;2:633-641.

https://doi.org/1981/P2/P29810000633

9. Nagaoka S, Okauchi $Y$, Urano S, Nagashima U and Mukai K. Kinetic and $a b$ initio study of the prooxidant effect of Vitamin E: Hydrogen abstraction from fatty acid esters and egg yolk lecithin. J Am Chem Soc. 1990;112(24):8921-8924. https://doi. org/10.1021/ja00180a042

10. Correale J, Ysrraelit MC and Gaitn MI. Immunomodulatory effects of Vitamin D in multiple sclerosis. Brain. 2009;132(5):1146-1160. https://doi.org/10.1093/brain/awp033

11. Baeke F, Takiishi T, Korf H, Gysemans C and Mathieu C. Vitamin D: Modulator of the immune system. Curr Opin Pharmacol. 2010;10:482-496.

https://doi.org/10.1016/j.coph.2010.04.001

12. Mathieu $\mathrm{C}$ and Badenhoop K. Vitamin D and Type 1 
diabetes mellitus: State of the art. Trends Endocrinol Metab. 2005;16(6):261-266.

https://doi.org/10.1016/j.tem.2005.06.004

13. Mora JR, Iwata M and von Andrian UH. Vitamin effects on the immune system: Vitamins $A$ and $D$ take centre stage. Nat Rev Immunol. 2008;8(9):685-698.

https://doi.org/10.1038/nri2378

14. Sadeghi K, Wessner B, Laggner U, Ploder M, TamandI D, Friedl J, et al. Vitamin D3 down-regulates monocyte TLR expression and triggers hyporesponsiveness to pathogen-associated molecular patterns. Eur J Immunol. 2006;36(2):361-370.

https: doi.org/10.1002/eji.200425995

15. Tarcin O, Yavuz DG, Ozben B, Telli A, Ogunc AV, Yuksel M, et al. Effect of Vitamin $D$ deficiency and replacement on endothelial function in asymptomatic subjects. J Clin Endocrinol Metab. 2009;94(10):4023-4030.

https: doi.org/10.1210/jc.2008-1212

16. Giovannucci E, Liu Y, Hollis BW and Rimm EB. 25-hydroxyvitamin $\mathrm{D}$ and risk of myocardial infarction in men: Prospective study. Arch Intern Med. 2008;168(11):1174-1180.

https//doi.org/10.1001/archinte.168.11.1174

17. Wang L, Song $Y$, Manson JE, Pilz S, März W, Michaëlsson K, et al. Circulating levels of 25hydroxy-vitamin $D$ and risk of cardiovascular disease: A meta-analysis of prospective studies. Circ Cardiovasc Qual Outcomes. 2012;5(6):819-829.

https://doi.org/10.1161/CIRCOUTCOMES.112.967604

18. Saini NR and Saini N. Liv-52 protection against radiation induced lesions in mammalian liver. Radiobiol Radiotber. 1985;26(3): 279-82.

https://doi.org/3903837

19. Malik KK and Pal MB. Liv.52 in hepatitis and cirrhosis of the liver. Curr Med Pract. 1979;23:5.

http://doi.org/liv-52.co.uk/Research/Cirrhosis/liv174

20. Dhumal MS, Mane IH and Patel SS. Effect of Liv-52 on carbon tetrachloride. Indian J Pharmacol. 1989;21:96-99.

21. Ohkawa $\mathrm{H}$, Ohishi $\mathrm{N}$ and Yagi $\mathrm{K}$. Assay for lipid peroxides in animal tissues by thiobarbituric acid reaction. Anal Biochem. 1979;95(2):351-358. https://doi.org/10.1016/00032697(79)90738-3

22. Parekh $A C$ and Jung $D H$. Cholesterol determination with ferric acetate-uranium acetate and sulfuric acid-ferrous sulfate reagents. Anal Chem. 1970;42:1423.

https://doi.org/10.1021/ac60294a044

23. Leffler $\mathrm{HH}$ and $\mathrm{McDougald} \mathrm{CH}$. Estimation of cholesterol in serum by means of improved technics. Am J Clip Pathol. 1963;39:311-315.

https://doi.org/13929259

24. Rouser G, Fleischer S, Yamamoto A. Two dimensional thin layer chromatographic separation of polar lipids and determination of phospholipids by phosphorus analysis of spots. Lipids. 1970;5(5):494-496.

https://doi.org/10.1007/BF02531316

25. Rice EC. In: Roberict $C$ and Medorald $P$, editors. Triglycerides in serum: Standard Methods of Clinical Chemistry. Vol. 6. New York: Academic Press; 1970. p. 215-222.

26. Hron WT and Menahan LA. A sensitive method for the determination of free fatty acids in plasma. J. Lipid Res. 1981;22(2):377-381. https://doi.org/7240964

27. Larrey D. Drug-induced liver diseases. J Hepatol. 2000;32(1 Suppl):77-88.
https://doi.org/10.1016/S0168-8278(00)80417-1

28. Liedtke C, Luedde T, Sauerbruch T, Scholten D, Streetz K, Tacke F, et al. Experimental liver fibrosis research: Update on animal models, legal issues and translational aspects. Fibrogenesis Tissue Repair. 2013;6(1):19. https://doi.org/10.1186/1755-1536-6-19

29. Nakano A, Kanda $T$ and Abe $H$. Bone changes and mineral metabolism disorders in rats with experimental liver cirrhosis. J Gastroenterol Hepatol. 1996;11(12):1143-1154. https://doi.org/10.1111/j.1440-1746.1996.tb01843.x

30. Stoyanovsky DA and Cederbaum Al. Metabolism of carbon tetrachloride to trichloromethyl radical: An ESR and HPLC-EC study. Chem Res Toxicol. 1999;12(8):730-736.

https://doi: 10.1021/tx9900371

31. Ramadori $G$ and Saile B. Portal tract fibrogenesis in the liver. Lab Invest. 2004;84(2):153-159.

https://doi.org/10.1038/labinvest.3700030

32. Saile B and Ramadori G. Inflammation, damage repair and liver fibrosis role of cytokines and different cell types. $Z$ Gastroenterol. 2007;45(1):77-86. https://doi.org/10.1055/s-2006-927395

33. Cheeseman KH, Albano EF, Tomasi A and Slater TF. Biochemical studies on the metabolic activation of halogenated alkanes. Environ Health Perspect. 1985;64:85-101. https://doi.org/10.1289/ehp.856485

34. Tribble DL, Aw TY and Jones DP. The pathophysiological significance of lipid peroxidation in oxidative cell injury. Hepatology. 1987;7(2):377-387. https://doi.org/10.1002/hep.1840070227

35. Murray RK, Granner DK, Mayes PA and Rodwell VW. Harper's Biochemistry. $23^{\text {rd }}$ ed. Stamford, Connecticut: Appleton and Lange; 1993. p. 258-265.

36. Boll M, Weber LW, Becker LE and Stampfl A. Pathogenesis of carbon tetrachloride in hepatocyte injury. Bioactivation of $\mathrm{CCl} 4$ by cytochrome P450 and effects on lipid homeostasis. Z Naturforsch. 2001;56(1-2):111-121.

htpps://doi.org/10.1515/znc-2001-1-218

37. Lieber CS. Alcoholic liver disease: New insights on pathogenesis lead to new treatment. J Hepatol. 2000;32(Suppl 1):113-128. https://doi.org/10.1016/s0168-8278(00)80420-1

38. Devarshi P, Kanase A, Kanase R, Mane S, Patil S and Varuthe AT. Effect of mandurbhasma on lipolytic activities of liver, kidney and adipose tissue of albino rat during $\mathrm{CCl} 4$-induced hepatic injury. J Biosci. 1986;10:227-234. https://doi.org/10.1007/BF02703480

39. Honma $T$ and Suda M. Changes in plasma lipo-proteins as toxicity markers for carbon tetrachloride, chloroform and dichloromethane. Ind Health. 1997;35(4):519-531. https://doi.org/10.2486/indhealth.35.519

40. Morrow JD, Awad JA, Boss HJ, Blair IA and Roberts LJ $2^{\text {nd }}$. Non-cyclooxygenase-derived prostanoids (F2- isoprostanes) are formed in situ on phospholipids. Proc Natl Acad Sci U S A. 1992;89(22):10721-10725.

https://doi.org/10.1073/pnas.89.22.10721

41. Wiggins D and Gibbons GF. Origin of hepatic verylow density lipoprotein triacylglycerol: The contribution of cellular phospholipid. Biochem J. 1996;320(Pt 2):673-679. https://doi.org/10.1042/bj3200673

42. Dobnig H, Pilz S, Scharnagl H, Renner W, Seelhorst U, Wellnitz B, et al. Independent association of low serum 25 -hydroxyvitamin 
d and 1,25-dihydroxyvitamin d levels with all-cause and cardiovascular mortality. Arch Intern Med. 2008;168(12): 1340-1349.

https://doi.org/10.1001/archinte.168.12.1340

43. Polkowska A, Głowińska-Olszewska B, Tobiaszewska M and Bossowski A. Risk factors for cardiovascular disease in children with Type 1 diabetes in 2000-2010 in Podlasie Province. Pediatr Endocrinol Diabetes Metab. 2014;20(2):47-54.

https://doi.org/10.18544/PEDM-20.02.0002

44. Mehrotra MP and Tandon S. Liv.52 a clinico-biochemical trial in hepatic cirrhosis. Curr Med Pract. 1973;4:185.

https://doi.org/92767609

\footnotetext{
Authors Contribution:

Work attributed to:

Orcid ID:

Dr. J. Sivakumar - (1) https://orcid.org/0000-0002-6944-7439

Mr. K. Ponnazhgan - (D) https://orcid.org/0000-0003-0781-3904

Source of Support: Nil, Conflicts of Interest: None declared.
}

JS - Concept and design of the study, prepared first draft of manuscript; KP - Statistical analysis and result interpretation; reviewed the literature and manuscript preparation; $\mathbf{G}$ - Concept, coordination, preparation of manuscript and revision of the manuscript.

Meenakshi Medical College Hospital and Research Institute, Enathur, Kanchipuram, Tamil Nadu, India, Pin-631552. 